\title{
THE EFFECT OF BURNOUT (FATIGUE) ON ENGAGEMENT EMPLOYEES PERMANENT EMPLOYEES AT PT. INDOSRPING Tbk GRESIK
}

\author{
Muhammad Ali Asyhar ${ }^{1}$, Awang Setiawan Wicaksono², Chandrania Fastari ${ }^{3}$ \\ Psychology Faculty, Universitas Muhammadiyah Gresik \\ asyharmuhammad8494@gmail.com¹ ,awangwicaksono.psi@umg.ac.id², $^{2}$ \\ chandraniafastari@umg.ac.id ${ }^{3}$
}

\begin{abstract}
This study aims to see whether or not there is a Burnout effect on the involvement of permanent employees of PT. Indospring Tbk. Employee engagement is an enthusiastic attitude of employees in doing their jobs, which is because employees put their energies into work and are in line with the company's strategic priorities. (Schaufeli et.al, 2002). Burnout is an emotional syndrome, depersonalization, and reduced personal achievement that can occur among individuals who work with people in multiple capacities (Maslach, 1996). This research was conducted on permanent employees who work at PT. Indospring Tbk Gresik with a sample size of 90 respondents. The data collection tools used are the Maslach Burnout Inventory (MBI) scale (22 valid items) compiled by Masclach (1996), the Ultrech Work Engineer Scale (UWES) (17 valid items) compiled by Schaufeli \& Bekker (2004). The reliability of the employee engagement scale (r) is 0.930 , and the reliability of the burnout scale (r) is 0.859 which means that it is lack of reliability. The data analysis used in this study is non-parametric statistics with non-linear regression test techniques with the help of SPSS 25.0 for Windows. Based on the analysis of research data using non-linear regression test, it can be concluded that the employee engagement variable by the burnout variable with a mathematical equation $y=83.405-0.331 x$. It can be accepted that $\mathrm{Ho}$ is rejected and $\mathrm{Ha}$ is accepted, so the simple non-linear regression analysis shows that there is a variable effect, namely fatigue of permanent employees of PT. Indospring Tbk. Gresik
\end{abstract}

Keywords: Burnout, Employee Engagement

\section{INTRODUCTION}

Every company/organization is faced with various demands and competition in running its business. The emergence of these demands, makes every company continue to make various efforts in order to survive and be the best (Sri Widodo \& Sami'an, 2013). These various demands ultimately force every company/organization to be able to compete with other organizations in order to survive in running their business. A company that will survive and be the best in the world of competition certainly does not escape the role of human resources (Ramadhani, et al. 2018). This is because the 
human resource factor is very crucial as a driver in maintaining, directing and developing the company (Hidayati, Purwanto, \& Yuwono, 2010).

Organizations need employees who not only have a high level of satisfaction at work, but also have a high commitment, are involved in running the organization's business and have high loyalty and have a sense of ownership in the organization or have a high level of attachment to the organization (Husniati, et al. 2018 ). This shows that the organization considers that employees are assets that need to be developed and the organization has high expectations for increasing employee commitment and engagement.

Employee engagement has become the most discussed topic in recent years among consulting companies and well-known business media (Saks, 2006 in Agnes Wahyu Handoyo: 2017). Employee engagement or employee engagement with the organization or work is very important for an organization and is the most influential factor on the high and low performance of a company (Triple Creek Associates, 2007 in Agnes Wahyu Handoyo: 2017).

Schaufeli et al., 2002 (in Simon Yuarto: 2017) employee engagement is a positive thing for individuals towards their work and is able to provide satisfaction for individuals. Attitudes and views related to the relationship of individuals with work can be characterized by three aspects, namely sincerity (vigor), dedication (dedication), and appreciation (absorption). These three aspects can appear in employees and have a positive impact on increasing employee productivity as shown by increasing work enthusiasm, creativity and innovation.

The importance of employee engagement is to make the company survive in the competitive world of the industry and achieve the target of the company's plan. Employee engagement is often discussed by companies (Saks, 2006). This is because employee engagement is important to ensure long-term growth and profit in an increasingly challenging business environment (Catteeuw, Flynn, \& Vonderhorst, 2007 in Mujiasih, 2015).

The existence of employee engagement in employees will make employees able to work comfortably and further demonstrate the quality of work. Engagement needs to be owned by employees so that employees can work optimally. The results of previous studies revealed that high engagement in the company can increase the value of the margin by $3.74 \%$ and the company's profit by $2.06 \%$. Low engagement in the company can make the value of margins and profits decrease (Schaufeli, 2013). This means that employee engagement has an impact on the sustainability of a company, especially on the value of a company's margin and profit.

In fact, based on the results of research conducted by the German Statistics Office, with collective data collection between 2012-2014 using the Gallup engagement measurement tool, the results of the analysis show that there are three elements of engagement to reduce work fatigue. The three elements are giving praise and recognition for good work, having materials and equipment to deliver quality work, and feeling that their opinions are taken into account in the workplace. Employees who gave a low rating for all of the above items with a percentage of $24 \%$ of all employees in Germany or approximately 2.7 million employees stated that they experienced burnout, and only $15 \%$ of employees were engaged, $31 \%$ felt stressed.

Maslach \& Leiter (1997), stated that burnout as an eroding employee's work engagement. Starting from work that is important, meaningful and full of challenges to be unpleasant, unsatisfactory and meaningless. According to Simon (2017), employee engagement has a different effect from Burnout and has a negative effect. When employee engagement decreases, it will increase burnout.

Schaufeli's research (in Timms et al., 2011) explains that employee engagement and burnout have opposite effects, so it can be interpreted that burnout that arises from within employees can be 
eliminated or eroded slowly if the employee is given the trust of a leader and given a reward. ) in accordance with their responsibilities. Through this study, researchers want to see the effect of burnout on permanent employee engagement further, researchers want to reveal in more detail the relationship between aspects of burnout and employee engagement.

\section{Method}

\section{Data source and sampling}

The subjects of this research are The population is a generalization area consisting of subjects or objects that have certain qualities and characteristics set by researchers to be studied and concluded (Sugiyono, 2015: 80). In accordance with this opinion, the researcher intends to take a population with the characteristics in question are permanent employees who work at PT. Indospring Tbk, has a minimum working period of one year, a maximum age of 40 (forty) years based on data obtained from the Human Capital (HC) department of PT. Indospring Tbk. totaling 871 (eight hundred and seventy one) employees.

The sampling technique in this study uses the Nonprobability Sampling technique, which is a sampling technique that does not provide equal opportunities/opportunities for each element or member of the population to be selected as samples (Sugiyono, 2017: 122). The approach used in this research is purposive sampling. Purposive sampling is a sampling technique with certain considerations (Sugiyono, 2017: 124).

\section{Measure}

The data collection technique in this study for the two variables was using the questionnaire method (questionnaire) which is a data collection technique carried out by giving a set of questions or written statements to respondents to answer (Sugiyono, 2015: 142). The questionnaire in this study was made in the form of statements relating to the variables studied based on the indicator variable (X) burnout and variable (Y) employee engagement and distributed to respondents (permanent employees) at PT. Indospring Tbk.

The measurement scale used in this study is the Likert scale which is made in tabular form. The Likert scale is a scale used to measure individual attitudes, opinions and perceptions about social phenomena (Sugiyono, 2015: 93). The reason the researcher uses the Likert scale is that it is expected that the variables in the research being measured are measurable and visible, then the variables to be measured are translated into variable indicators, then these indicators are used as a starting point for compiling statement items.

In this study, the instrument used was adopted from the Maslach Burnout Inventory (2004) scale. The adoption process starts from translating the scale into Indonesian and then validated by expert judgment. Alternative answer choices Likert Scale on the burnout variable, each item consists of 7 categories of answers as follows; $0=$ Never, $1=\mathrm{A}$ few times a year, $2=$ Once a month, $3=\mathrm{A}$ few times a month, $4=$ Once a week, $5=\mathrm{A}$ few times a week and $6=$ Every day.

The instrument used in this study was adopted from the Ultrech Work Engagement Scale (1994). The adoption process starts from translating the scale into Indonesian and then validated by expert judgment. Alternative answer choices for the Likert Scale on the employee engagement variable, each item consists of 7 categories of answers as follows; $0=$ Never, 1=Almost Never, $2=$ Rarely, $3=$ Sometimes, $4=$ Often, $5=$ Very Often and $6=$ Always. 


\section{Analysis}

The data analysis technique used in this research is simple linear regression analysis, namely regression analysis technique with one independent variable. Regression analysis is used to find out how the dependent variable can be predicted through independent variables or predictors individually/partial or jointly/simultaneously (Sugiyono, 2015: 154). After the statistical analysis process used in this study, the computer program tools IBM Statistical Program for Social Science (SPSS) for windows version 25.0 was used.

\section{Result}

The results of the normality test showed that the variables were not normally distributed and the linearity test showed that the variables had a linear relationship. So to determine the effect between variables, non-parametric statistical approaches are used and non-linear regression data analysis techniques are used. Researchers tested non-linear regression using the SPSS 25.0 for windows program.

The hypothesis proposed by the researcher is as follows:

Ho : There is no effect of burnout on employee engagement of permanent employees PT. Indospring Tbk.

Ha : There is an effect of burnout on employee engagement of permanent employees of PT. Indospring Tbk.

If the significance value is $<0.05$, it means that there is an influence between burnout and employee engagement.

Based on the regression test on the burnout dimension, the Rsquare value is 0.138 , which means that burnout has an effect of $13.8 \%$ on employee engagement. While $86.2 \%$ is influenced by other factors not examined. It is known that the employee engagement variable is 83,405 while the burnout value is -0.331 . These results show the regression line between burnout and employee engagement variables.

The Coefficients table is used to determine the regression coefficient and the influence of the $\mathrm{X}$ variable on the $\mathrm{Y}$ variable. The coefficients table shows that the independent variable (burnout) that is included in the model is significant, this can be seen from the probability that its significance is far below 0.05 . So it can be concluded that the employee engagement variable is influenced by the burnout variable with the mathematical equation $y=83.405-0.331 \mathrm{x}$. So it can be said that the lower the level of burnout in individuals, the higher the level of employee engagement.

\section{Discussion}

Based on the results of data analysis, it is stated that there is a positive and significant influence between burnout on employee engagement. This is evidenced by the results of the non-linear regression test in the coefficient table, the t-statistic value for the burnout variable is -3.746 with sig $=0.000<0.05$. This means that it is concluded that there is a 
significant influence between burnout on employee engagement, so that individuals who have a low level of burnout have a higher level of engagement with the company.

Burnout favorite item that many permanent employees of PT. Indospring Tbk, among others: item number 14 with a percentage of $35.5 \%$, namely "I feel I work too hard at work". Followed by item number 2 the statement "I feel very tired at the end of the work day" with a percentage of $32.2 \%$.

Based on the burnout favorite items that were chosen, it shows that most of the permanent employees who work at PT. Indospring Tbk. have indicated employees experience emotional exhaustion and an increased tendency for individuals to stay away from their surroundings.

The burnout unfavorable item that was chosen by many permanent employees of PT. Indospring Tbk, among others: item number 7 with a percentage of $77.8 \%$, namely "I can handle work problems objectively". Followed by item number 12 the statement "I feel very energetic or excited" with a percentage of $86.7 \%$.

Based on the most selected burnout unfavorable items, it shows that some permanent employees who work at PT. Indospring Tbk. reflects a feeling of competence to achieve targets in one's work. This self-achievement is indicated if high burnout will result in low achievement.

Based on the discussion above, it can be concluded that there is a significant influence between burnout on employee engagement. This means, the lower the burnout level, the more it affects the level of permanent employee engagement at PT. Indospring Tbk. In addition to the results of this study, researchers are also supported by data on the level of permanent employee engagement at PT. Indospring Tbk. which is quite high, which is $83 \%$ engagement rate (Human Capital PT. Indospring Tbk., 2020).

\section{Conclusion}

Based on the results of the analysis of research data using a non-linear regression test, it can be concluded that the employee engagement variable is influenced by the burnout variable with the mathematical equation $y=83.405-0.331 x$. It can be concluded that Ho is rejected and $\mathrm{Ha}$ is accepted, so that a simple non-linear regression analysis shows that there is an influence of the independent variable, namely burnout on employee engagement of permanent employees of PT. Indospring Tbk. Gresik.

In addition, the regression test on the burnout dimension obtained an $\mathrm{R}$-square value of 0.138 , which means that burnout has an effect of $13.8 \%$ on employee engagement. While $86.2 \%$ is influenced by other factors that are not studied. These results indicate that when an employee has a high burnout, it will affect the level of employee engagement. 


\section{REFERENCES}

Akbar, R. M. (2013). Pengaruh Budaya Organisasi Terhadap Employee Engagement (Studi Pada Karyawan PT. Primatexco Indonesia di Batang). Journal of Social \& Industrial Psychology.

Albrecht, S. L. (2010). Handbook of Employee Engagement. Northmpton, Edward Wdgar Publishing, Inc.

Anita, J. (2014). Determinant of Employee Engagement and their Impact on Employee Performance. International Journal of Productivity and Performance Manager, 308-323. Azwar, Saifuddin (2014). Metode Penelitian. Yogyakarta: Pustaka Belajar

Bogue, R. \&. (2019). Extinguish Burnout: a Practical Guide To Prevention and Recovery. Unit State of America: SHRM. Blessing White, (2011) : https://instituteforpr.org/employee-engagement-2/

Cahyadi, A. (2017). Pengaruh Keterikatan Karyawan Terhadap Kinerja Karyawan PT. Badja Baru Palembang. Jurnal Bisnis dan Manajemen Terapan.

Carolyn, T. E. (2012). Burnout But Engaged: The Co-Existence of Psychological Burnout and Engegament. Journal of Educational and Administration, 327-345.

Chairiza, D. D. (2018). Pengaruh Burnout dan Employee Engagement terhadap intensi Turn Over Karyawan Hotel. Analitika Jurnal Magister Psikologi UMA, Vol. 10, No. 2.

Demerouti, E., \&. M. (2010). Burnout and Work Engagemet: A Trought Investigation of Independency of Both Constructs. Journal of Occupational Health Psychology, 209-222. Fauzi, O. \&. (2016). The Influence Of Employee Engagement Toward Employee Performance In PT. Studio Cilaki Empat Lima Bandung .

Gallup, W. H. (2004). How Millennials Want to Work and Live. Washington D.C: The Gallup Biulding.

Handoyo, A. W. (2017). Pengaruh Employee Engagement Terhadap Kinerja Karyawan PT. Tirta Rejeki Dewata. AGORA, Vol. 5, No. 1.

Herter, P. \&. (n.d.). Cross-Cultural Analysis of Gallup's Q12 Employee Engagement Instrument. Gallup Consulting.

Hikmatullah, F. (2016). Hubungan Employee Engagement dengan Burnout pada Karyawan Divisi IT . Jurnal Ilmiah Psikologi, 100 - 108.

Indrianti R, \&. H. (2012). Hubungan Antara Modal Psikologis dengan Keterikatan Kerja Pada Perawat di Instalasi Rawat Inap Rumah Sakit Jiwa Surabaya. Jurnal Psikologi Industri \& Organisasi Fakultas Psikologi Universitas Airlangga Surabaya, Vol. 1 No. 02. Kristiana, I. D. (2018). Analisis Rasch Dalam Ultrecth Work Engagement Scale - 9 (UWES-9) Versi Bahasa Indonesia. Jurnal Psikologi Vol. 17 No. 2, 204-217.

Langelaan, S. (2006). Burnout \& Employee Engagement: Do Individual Differences and Make a Difference? Personality and Individual Difference, 521-532.

Liza, F. D. (2019). Literatur Study : Validity \& Reliability Tes1 of Maslach Instrumen Burnout Inventory - Human Service Instrument in Nurse in Several Countries. Jurnal of Nursing Science, Vol. 7 No. 2. 
Macey,. Schneider,. Barbera, \&. Y. (2008). The Meaning of Employee Engagement. Journal of Industrial \& Organizational Psychology.

Masclah, C. (1981). The Measurement of Experinece Burnout. Journal Of Occupational Behavior.

Maslach, C. (2001). Job Burnout. Amerika: Eastem Kentucky University.

Mujiasih, \&. R. (2012). Meningkatkan Work Engagement Melalui Gaya Kepemimpinan Transformasional dan Budaya Organisasi. Fakultas Psikologi Universitas Diponegoro Semarang.

Mujiasih, E. (2015). Hubungan Antara Persepsi Dukungan Organisasi Dengan Keterikatan Karyawan. Jurnal Psikologi Undip, 40 -51.

Nusatria, S. (2017). Employee Engagement :Anteseden \& Konsekuensi.

Perrin, T. (2003). Working Today: Understanding What Drivers Employee Engagement. U.S Report.

Pupadewi, Ulfa, \&. S. (2016). Analisis Employee Engagement pada Perusahaan Jasa (Studi pada Karyawan Patra Jasa Convention Hotel Semarang. Vol. 5 No. 3.

Putra.Y.S, \&. M. (2010). Pengaruh Job Demand Terhadap Kinerja Dengan Burnout Sebagai Variabel Moderating Pada Karyawan Bagian Produksi PT.Tripilar Betonmas Salatiga. Among Makarti, 47-68.

Ramadhani, Y.N, \&. H. (2018). Pengaruh Job Demand Resource Terhadap Employee Engagement Pada Staff Account Officer PT. X Wilayah Jombang. Jurnal Psikologi Industri \& Organisasi, 1-15.

Rizza, M. A. (2013). Pengaruh Budaya Organisasi terhadap Employee Engagement (Studi pada karyawan PT. Primatexco Indonesia Di Batang). Journal of Social and Industrial Psychology.

San,.T, \&. Y. (2018). Keterikatan Karyawan dipengaruhi oleh Kecerdasan Emosional dan Model Psikologi. 640-655.

Santosa, T. C. (2012). Memahami dan Mendorong Terciptanya Employee Engagement Dalam Organisasi. Jurnal Manajemen, Vol. 11, No. 2.

Schaufeli, W., \&. B. (2004). Ultrecht Work Engagement Scale (UWES) Preliminary Manual. Germany: Occupational Health Psychology Unit Ultrech University.

Schaufeli,. Salanova, G.-R. \&. (2001). The Measurement of Engagement and Burnout And: A Confirmative Analytic Approach . Journal of Happiness Study.

Titien. (2016). Penyusunan dan Pengambangan alat ukur Employee Engagement. Psikohumaniora: Jurnal Penelitian Psikologi, 207-216.

Widhiarso, W. (2008). Koefisien Reliabilitas untuk Pengukuran Kepribadian Multidimensi. Jurnal Psikobuana, Vol. 1 No. 39-48.

Widodo, \&. (2013). Hubungan Employee Engagement Dengan Perilaku Produktif Karyawan. Jurnal Psikologi Industri dan Organisasi.

Yuarto, S. (2017). Pengaruh Employee Engagement Terhadap Burnout. Jurnal Psikologi. Yulianto, H. (2020). Maslach Burnout Inventory - Human Servive Survey (MBI-HSS) Versi Bahasa Indonesia : Studi Validasi Konstruk Pada Anggota Polisi. Jurnal Pengukuran Psikologi \& Pendidikan Indonesia, 19-29. 